\title{
Study on the differences in quantitative ultrasound of the quadriceps between schoolchildren who practise different sports
}

\author{
Juan C. Giraldo García ${ }^{1,2}$, Alex N. Meneses Oquendo², Elena Hernández Hernández \\ "Universidad Pablo de Olavide. Sevilla. ${ }^{2}$ Institución Universitaria Politécnico Colombiano Jaime Isaza Cadavid. Medellín. Colombia.
}

doi: 10.18176/archmeddeporte.00012

Received: 20/12/2019

Accepted: 28/09/2020

Key words:

Child. Ultrasonography. Sports. Muscle development. Quadriceps muscle.

\section{Summary}

Objective: To evaluate the differences in quantitative ultrasound of the quadriceps in a sample of schoolchildren who practise different sports.

Material and method: A transversal, comparative and non-randomised study was carried out with an intentional sample of 184 schoolchildren, aged between 7 and 10 years. The sample was divided into three groups based on the sport practised: a) only soccer; b) volleyball, basketball, swimming, gymnastics and cheerleading; and c) no sport practised. The eco-intensity, thickness and pennation angle of some components of the quadriceps (rectus femoris, vastus lateralis and vastus intermedius) were measured using B-mode ultrasound imaging.

Results: There were significant differences between the 3 groups of children in the variables that measure the quality of the muscle: eco-intensity and fat percentage of the rectus femoris $(p<0.05)$, muscle thickness of the anterior $(p<0.05)$ and lateral $(p<0.01)$ vastus intermedius, and in the pennation angle of the rectus femoris (ARF) $(p<0.05)$ and of the vastus lateralis (AVL) $(p<0.01)$. Between groups $b$ and $c$ there were differences in the ARF in boys $(p<0.01)$ and in the AVL in girls $(p<0.05)$.

Conclusion: The way in which sport initiation is carried out in children between 7 and 10 years of age may cause differences in the quadriceps muscle, which can be demonstrated through the use of quantitative ultrasound. Moreover, such differences are related to the duration and frequency of the stimulus, which becomes a qualitative aspect to be considered when programming the training contents at these ages.
Palabras clave: Niños. Ultrasonografía. Deportes. Desarrollo muscular. Músculo cuádriceps.

\section{Estudio sobre las diferencias en ecografía cuantitativa del cuádriceps entre escolares practicantes de diferentes modalidades deportivas}

\section{Resumen}

Objetivo: Evaluar las diferencias en ecografía cuantitativa del cuádriceps en niños y niñas escolares practicantes de diferentes deportes.

Material y método: Se realizó un estudio transversal, comparativo y no aleatorizado. Se utilizó una muestra intencional compuesta por 184 niños escolares, entre 7 y 10 años. La muestra fue dividida en tres grupos según la modalidad deportiva practicada: a) un grupo que solo practicaba fútbol; b) otro grupo donde practican voleibol, baloncesto, natación, gimnasia y cheerleading; y c) un grupo que no practican ninguna modalidad deportiva. La eco-intensidad, el espesor y el ángulo de penneación de algunos componentes del cuádriceps (recto femoral, vasto lateral y vasto intermedio) fueron medidos usando una ecografía en modo-B.

Resultados: Hubo diferencias significativas al evaluar los 3 grupos en los niños, en las variables que miden la calidad del músculo: Eco-intensidad y porcentaje de grasa del recto femoral (v.p. $<0,05)$, el espesor muscular del vasto intermedio tanto anterior (v.p. $<0,05)$, como lateral (v.p. $<0,01)$, y en el ángulo de penneación del recto femoral (ARF) (v.p. $<0,05)$ y del vasto lateral (AVL) $(v$.p. $<0,01)$. Entre los grupos b y c se encontraron diferencias en el ARF en niños (v.p. $<0,01)$ y en el AVL en niñas $(v \cdot p .<0,05)$. Conclusión: La forma en la que se realice la iniciación deportiva en niños entre 7 y 10 años puede generar diferencias en el músculo del cuádriceps, que pueden hacerse evidentes mediante el uso de la ecográfica muscular cuantitativa. Esos cambios están además relacionados con la duración y la frecuencia del estímulo, lo cual supone un aspecto cualitativo para tener en cuenta durante la programación de los contenidos de entrenamiento en estas edades. 


\section{Introduction}

Skeletal muscle in growing children has not been thoroughly studied due to the requirement of invasive methods, such as biopsies, which, for ethical reasons, cannot be applied in minors. However, advancements in imaging techniques have progressively changed the situation and, nowadays, studies are being conducted with children and adolescents, even longitudinal studies, to analyse the muscle tissue at the metabolic and biochemical levels with magnetic resonance $(\mathrm{MRI})^{1}$, although there are still few data available. According to these studies, the estimated growth rate in the arm and leg muscle thickness of schoolchildren is similar before adolescence. During childhood, the muscle fiber of boys and girls has a similar diameter, and it is during adolescence when the adult fiber thickness is reached ${ }^{2}$

To evaluate the evolution of skeletal muscle in growing children, different measurements have been employed, such as muscle strength, muscle power, anthropometry, magnetic resonance imaging (MRI), computerised tomography (CT) and ultrasonography (US). US and dual energy x-ray absorptiometry (DEXA) can provide beneficial reference information for the follow-up of adaptations to training, nutritional regimes and injuries ${ }^{3,4}$. Some studies have demonstrated that the effects of strength training on the physiological cross-sectional area of the muscle and on strength in children have a similar direction and a different magnitude with respect to adults 5 . It has also been reported that muscle strength, muscle thickness and eco-intensity (EI) (the latter two measured by US) are affected by changes in body weight, height and age in minors. This influence only shows relevant changes in muscle strength and muscle thickness, since little is known about changes in muscle quality measured by El. The few studies that have analysed these effects show significant changes in healthy children ${ }^{6}$. El in adults increases along the years, whereas in children it is not associated with age. That is, throughout childhood, during the normal development of the muscles, El does not change significantly ${ }^{7,8}$. In any case, there is little information about the effects of physical activity and sport training on muscle quality measured by US through El.

Studies based on the evaluation of strength reveal that muscle quality is similar between genders during childhood, evidenced by the lack of differences when strength is expressed in relation to muscle mass or to the physiological cross-sectional area (PCSA). PCSA is a great predictor of strength in children ${ }^{9}$ and muscle thickness measured by US, which is easy to carry out, has an excellent correlation with PCSA ${ }^{10}$. In fact, between 5 and 10 years of age, children accumulate lean body mass at a similar rate. However, environmental factors, particularly the intensity and duration of physical activity, are related to the small differences in motor performance that appear between genders at that age range ${ }^{11}$.

The way in which schoolchildren are initiated in sports can be approached from different perspectives. On the one hand, specific or vertical initiation is characterised for focusing on the acquisition of learning and technical-tactical elements of a specific sport. Since there is a repetition of movements during the acquisition of such execution patterns, there is also specific stimulation of the muscle groups involved in those movements. On the other hand, there is a horizontal or nonspecific initiation, also known as multisport initiation ${ }^{12}$, which focuses on making use of the common characteristics of several sports, with the aim of acquiring competences and learning that can be extrapolated to other sports. Since there is variability in the proposed technical-tactical situations, the stimulation of the muscles involved in those movements is also multiple, and less specialised.

Therefore, the hypothesis proposed in this work is that the way in which a person is initiated in sports may influence the development of some of the muscles involved in the most repeated movements. Thus, the aim of the present study was to analyse the differences in quantitative ultrasound of the quadriceps in children who had been initiated in sports in different ways.

\section{Material and method}

\section{Participants}

The study was conducted in an intentional sample of 184 schoolchildren, 75 girls ( $9.41 \pm 0.91$ years old) and 109 boys ( $8.97 \pm 1.14$ years old), from two sports initiation schools and a primary education school of Medellin, Colombia. The exclusion criteria considered were: the presence of cardiovascular or metabolic disease, muscle-bone lesions or sexual maturation self-reported Tanner stage different from $1^{13}$. The children and their parents signed an informed assent and consent, respectively. The study protocol was approved by the ethics committee of the Jaime Isaza Cadavid Colombian Polytechnic University. The characteristics of the participant groups are shown in Table 1.

Table 1. Descriptive statistics.

\begin{tabular}{|c|c|c|c|c|c|c|}
\hline & \multicolumn{3}{|c|}{ Boys } & \multicolumn{3}{|c|}{ Girls } \\
\hline & Soccer & Multisport & No sport & Soccer & Multisport & No sport \\
\hline$n$ & 81 & 15 & 13 & 1 & 43 & 31 \\
\hline Age (years) & $8.9 \pm 1.16$ & $9.2 \pm 1.04$ & $9.8 \pm 0.55$ & 10.7 & $9.1 \pm 1.07$ & $9.8 \pm 0.55$ \\
\hline Hight (cm) & $133.8 \pm 8.61$ & $134.9 \pm 8.12$ & $137.9 \pm 7.08$ & 138 & $134.7 \pm 8.07$ & $138.3 \pm 7.23$ \\
\hline Weight (Kg) & $31.5 \pm 8.40$ & $32.5 \pm 7.79$ & $34.9 \pm 6.65$ & 29.4 & $32.2 \pm 7.81$ & $34.9 \pm 6.62$ \\
\hline Fat $\%$ & $16.23 \pm 7.07$ & $17.23 \pm 6.63$ & $18.81 \pm 5.95$ & 10.07 & $17.06 \pm 6.70$ & $18.64 \pm 5.89$ \\
\hline BMI $\left(\mathrm{Kg} / \mathrm{m}^{2}\right)$ & $17.4 \pm 3.19$ & $17.7 \pm 2.96$ & $18.3 \pm 2.90$ & 15.44 & $17.6 \pm 3.05$ & $18.2 \pm 2.85$ \\
\hline
\end{tabular}




\section{Design}

A transversal, comparative, non-randomised study was carried out. All participants attended either the laboratory of the Jaime Isaza Cadavid Colombian Polytechnic University or a room adapted to serve as a laboratory in the facilities of the San José de las Vegas School and the Lucrecio Jaramillo School (all three institutions located in Medellin, Colombia), between October 2018 and March 2019, where the following anthropometric measurements were recorded: body weight, height and fat percentage. Then, ultrasound imaging was conducted on the right quadriceps of the participants. The study variables are described below.

\section{Quantitative ultrasound}

Transversal and longitudinal images were obtained for the quadriceps femoris of the right leg using a B-mode ultrasound imaging device (B-Ultrasonic Diagnostic System, Contec, CMS600P2, Republic of China). A linear transducer (gain: 58, frequency: $7.5 \mathrm{MHz}$; depth: $6 \mathrm{~cm}$ ), covered with enough water-soluble transmitter gel to avoid the compression of the dermal surface, was placed on two anatomical points: 1) in the anterior region, at the middle point between the antero-superior iliac spine, and 2) in the lateral region, at the middle point between the anterosuperior iliac spine and the superior-external angle of the patella. In each anatomical point, longitudinal and transversal ultrasound sections were performed to evaluate the femoral rectus and vast intermediate (anterior region $)^{14}$ and the vast lateral and vast intermediate (lateral region) ${ }^{15}$. The subjects were evaluated in supine position, at a minimum rest of $5 \mathrm{~min}$, and they were asked to do no vigorous physical effort that day before the measurement. Two longitudinal and two transversal images were taken for each middle point. The frozen image was digitalised and later analysed using the ImageJ free software (National Institute of Health, USA, v.IJ 1.46). The anterior transversal images were used to measure the muscle thickness of the rectus femoris (lower margin of the anterior fascia of the rectus femoris to the upper margin of the posterior fascia of the rectus femoris), the thickness of the vastus intermedius (lower margin of the intermuscular fascia and the periosteum of the femur), and the total thickness of the anterior quadriceps (lower margin of the rectus femoris to the periosteum of the femur) (Figure 1) ${ }^{14}$. The lateral transversal images were used to measure: the muscle thickness of the vastus externus (lower margin of the anterior fascia of the vastus externus to the upper margin of the posterior fascia of the vastus externus), the thickness of the vastus intermedius in lateral view (lower margin of the intermuscular fascia and the periosteum of the femur), and the total thickness of the lateral quadriceps (lower margin of the vastus externus to the periosteum of the femur) (Figure 2$)^{15}$. The transversal images were also used to determine the El of the different muscles evaluated using the histogram tool in ImageJ. The region of interest was selected as the largest rectangular area of each muscle excluding fascia. The mean of the two images was expressed as a value between 0 (black) and

Figure 1. Images of the anterior region of the thigh.

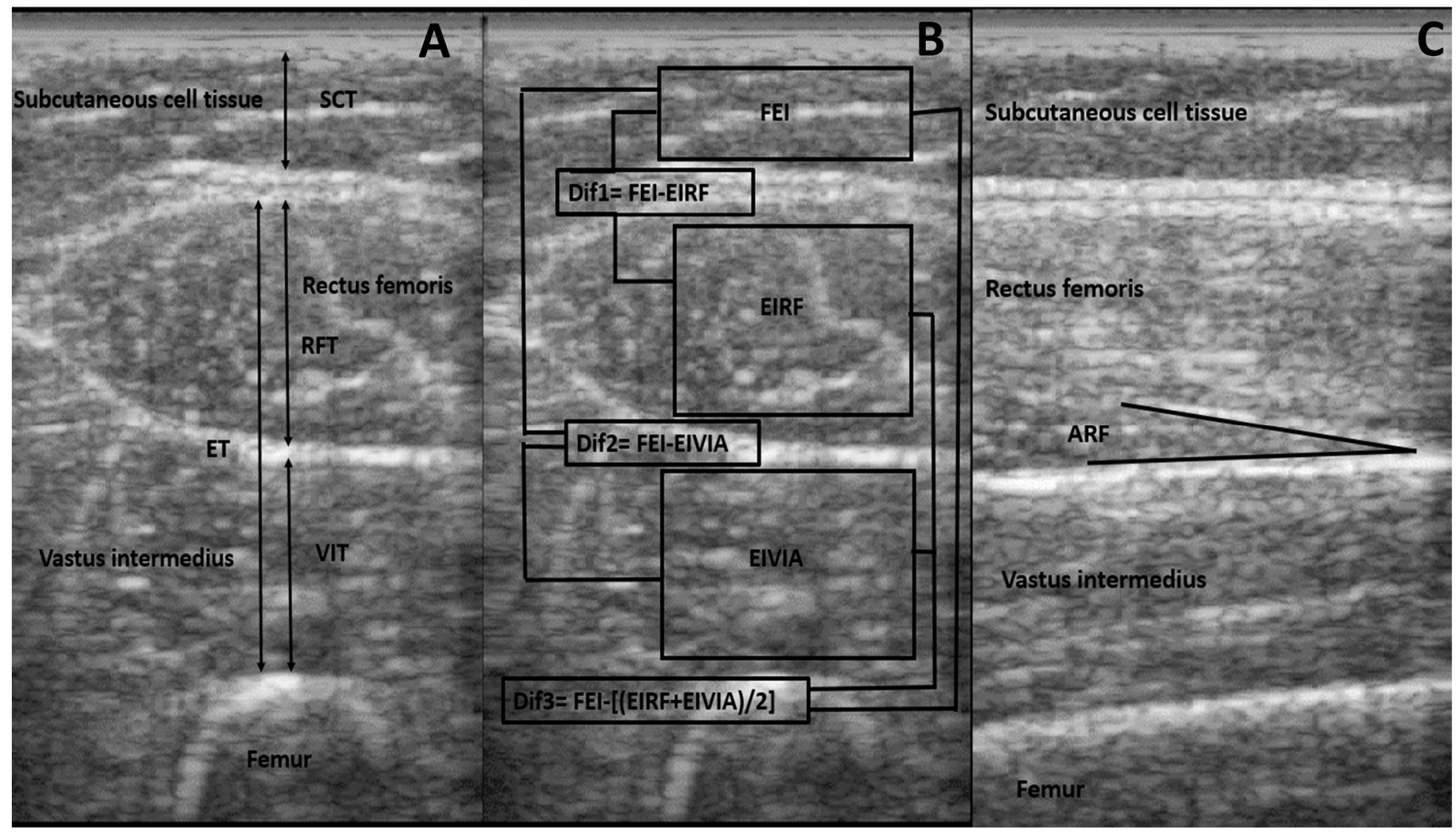

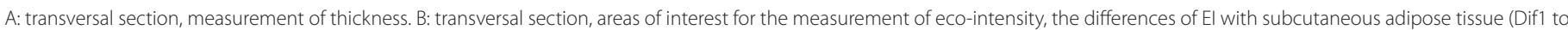
Dif3) and the \% of muscle fat. C: longitudinal section and measurement of the pennation angle. 
Figure 2. Images of the lateral region of the thigh.

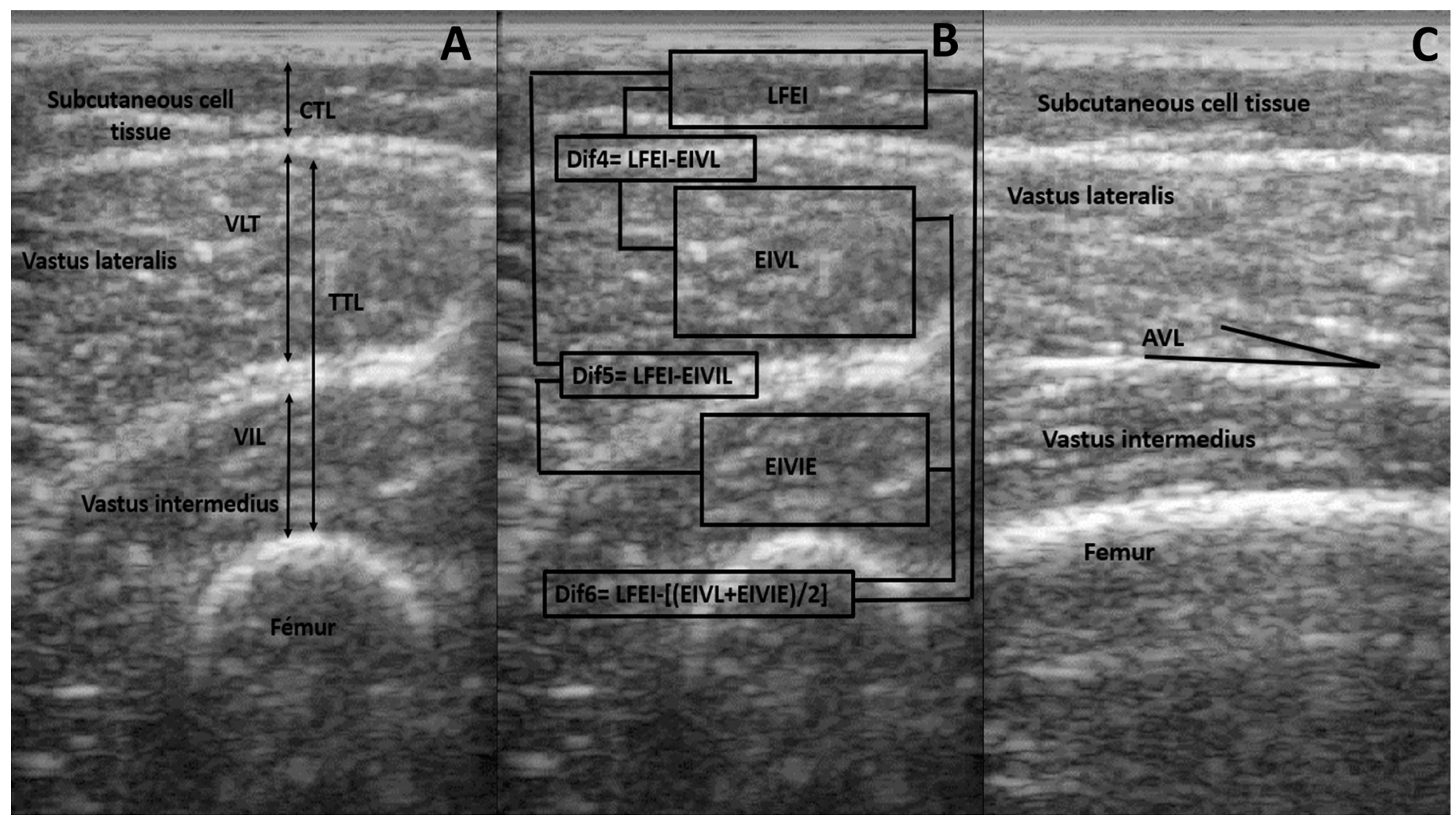

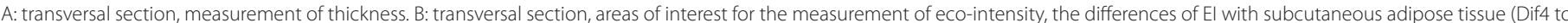
Dif6) and the \% of muscle fat. C: longitudinal section, measurement of the pennation angle.

225 (white). The El was correlated to the subcutaneous cell tissue, as suggested by Young, and the fat percentage was measured using the method proposed by the same author for every muscle ${ }^{16}$. Moreover, as a control strategy, the difference in fat El with respect to each portion of the quadriceps evaluated was also determined (Dif1 to Dif6) ${ }^{17}$. The longitudinal images were used to determine the pennation angle of the rectus femoris and the vastus externus. The values used for the statistical analysis of the muscle thickness and the penetration angle were the mean of the two measurements of each image. The coefficient of variation of two measurements, at different moments of the same day for ten subjects, was 5\%, $0.4 \%$ and $0.8 \%$ for muscle thickness, El and pennation angle, respectively.

\section{Anthropometry}

Body mass and height were measured without footwear and in sports clothes. Body fat percentage was estimated following Lohman's method for skinfolds measured in two places: triceps and subscapula ${ }^{18}$.

\section{Sports}

Sports practice was divided into three groups. The vertical sport initiation group (soccer), was composed of children who only practised soccer. This group trained 3 times per week (tuesday, thursday and sa- turday), for 120 minutes per session. The structure of the training session approaches physical, technical and tactical contents from an integral perspective, applying such contents to specific game situation. The training sessions were divided into 8 blocks, which included stretching, core proprioception and stability, strength, speed, aerobic resistance, general technique, specific technique, sectorial soccer and integrated competitive soccer. The horizontal sport initiation group (multisport) was constituted by children who practised volleyball, basketball, swimming, gymnastics and cheerleading. The training of the multisport group included mostly contents related to physical coordination attributes and, secondarily, physical condition attributes. Obviously, by working on the different motor capacities and abilities, the children also developed their physical condition. This group applied a global and playful methodology, with no special influence on the development of any attribute. The multisport children trained once per week, for 3 hours, rotating through different sports. Only the girls who practiced cheerleading trained twice per week, for 1.5 hours per session. The third group (no sport) did not practise any sport in a sport club on a regular basis.

\section{Statistical analysis}

The descriptive analysis of the sociodemographic and ultrasound aspects was carried out using absolute frequencies, relative frequencies and summary indicators such as arithmetic mean, standard deviation, 
median, interquartile range, and minimum and maximum values. The normality criterion of some variables was established using the ShapiroWilk test, and the homoscedasticity criterion was determined by the Levene test. To establish the relationship between the sociodemographic aspects (gender - sport group) and the ultrasound aspects, the Student T-test or the Mann-Whitney U-test was applied to compare two different groups, and for three-group comparisons, the single factor ANOVA test or the Kruskal-Wallis test was used, establishing $\mathrm{p}<0.05$ as statistically significant. The entire statistical process was conducted using the Stata software (Statacorp, v.16.0, College Station, Texas, USA).

\section{Results}

The sample was divided into 3 groups according to the sport practised and also by gender. Due to the fact that only one girl practised soccer, she was excluded from the statistical analysis. Consequently, the statistical analysis of the girls only included two groups: multisport and no sport. Table 2 shows the results of the boys in the three groups, and Table 3 presents the results of the two groups for boys and girls.

\section{Discussion}

\section{Eco-intensity}

In this study, statistically significant differences were found between the children who practised soccer and the other two groups of participants in the El of the rectus femoris and vastus intermedius (EIRF, FPRF, Dif1, Dif3). These differences appear in the measurements that include the rectus femoris. Previous studies without the type of sport initiation as a differentiating variable have shown that El in children does not change during normal growth ${ }^{19}$. A study conducted by Jacobs et al. (2013), with 25 children aged between 0 and 12 years, concluded that eco-intensity was not influenced by weight, height or age in healthy children, since the changes observed were not significant ${ }^{6}$. Another study reported that no changes were observed in age in the grayscale level, since there were no abnormal deposits of fat or connective tissue ${ }^{20}$. As the muscle grows, the ultrasound images will start showing the different muscle membranes, which can increase the El ${ }^{6,7}$, although muscle fiber thickness increases, which decreases the contribution of fibrous tissue, thus increasing the muscle tissue and, consequently, decreasing the El. In the

Table 2. Distribution of the quantitative ultrasound characteristics according to sport type (boys).

\begin{tabular}{|c|c|c|c|c|c|}
\hline & & $\begin{array}{l}\text { Soccer } \\
(n=81)\end{array}$ & $\begin{array}{l}\text { Multisport } \\
(n=15)\end{array}$ & $\begin{array}{l}\text { No sport } \\
(n=13)\end{array}$ & p value \\
\hline $\mathrm{FEI}^{*}$ & Fat El anterior region of the thigh & $146.19(13.19)$ & $145.47(11.36)$ & $141.16(11.57)$ & 0.2021 \\
\hline EIRF & El of the rectus femoris & $155.41 \pm 19.40$ & $168.85 \pm 13.89$ & $164.72 \pm 15.47$ & $0.0162 \dagger$ \\
\hline FPRF & Fat $\%$ of the rectus femoris & $19.12 \pm 1.79$ & $20.36 \pm 1.28$ & $19.97 \pm 1.42$ & $0.0162 \dagger$ \\
\hline EIVIA & $\mathrm{El}$ of the $\mathrm{VI}$ anterior thigh & $142.28 \pm 16.82$ & $145.28 \pm 12.81$ & $148.92 \pm 11.54$ & 0.3375 \\
\hline FPVI & Fat $\%$ of the $\mathrm{VI}$ & $21.41 \pm 1.90$ & $21.72 \pm 1.45$ & $22.15 \pm 1.30$ & 0.3491 \\
\hline Dif1 & Difference between FEI and EIRF & $-7.99 \pm 24.64$ & $-24.61 \pm 18.43$ & $-21.46 \pm 20.88$ & $0.0148 \dagger$ \\
\hline Dif2 & Difference between FEI and EIVIA & $5.13 \pm 20.34$ & $-1.03 \pm 17.31$ & $-5.65 \pm 16.49$ & 0.1307 \\
\hline Dif3 & Difference between FEI and median of EIRF and EIVIA & $-1.43 \pm 21.26$ & $-12.82 \pm 16.86$ & $-13.56 \pm 17.82$ & $0.0351+$ \\
\hline LFEI & Fat El lateral region of the thigh & $135.07 \pm 11.81$ & $134.45 \pm 11.19$ & $138.55 \pm 9.12$ & 0.5631 \\
\hline EIVL & El of the vastus lateralis & $161.54 \pm 18.11$ & $168.23 \pm 16.33$ & $170.53 \pm 11.76$ & 0.1207 \\
\hline FPVL & Fat $\%$ of the vastus lateralis & $23.62 \pm 2.05$ & $24.37 \pm 1.85$ & $24.63 \pm 1.32$ & 0.1224 \\
\hline EIVIE & El of the VI external thigh & $139.14 \pm 19.24$ & $137.77 \pm 13.77$ & $142.16 \pm 11.26$ & 0.7986 \\
\hline FPVIE & Fat $\%$ of the $\mathrm{VI}$ external region & $21.06 \pm 2.18$ & $20.90 \pm 1.56$ & $21.39 \pm 1.28$ & 0.8058 \\
\hline Dif4 & Difference between $\mathrm{FEl}$ and $\mathrm{El}$ of the $\mathrm{VL}$ & $-26.47 \pm 17.83$ & $-33.78 \pm 15.33$ & $-31.91 \pm 9.83$ & 0.2101 \\
\hline Dif5* & Difference between FEI and EIVI external region & $-6.06(22.83)$ & $-4.85(32.32)$ & $-5.01(22.11)$ & 0.9553 \\
\hline Dif6* & Difference between $\mathrm{FEI}$ and median of EIVL and VI external region & $-16.61(23.65)$ & $-22.15(24.64)$ & $-19.28(13.18)$ & 0.7192 \\
\hline $\mathrm{SCT}^{*}$ & Subcutaneous cell tissue & $5.79(4.71)$ & $7.86(3.79)$ & $9.57(5.43)$ & $0.0216 \dagger$ \\
\hline $\mathrm{RFT}^{*}$ & Rectus femoris thickness & $18.86(4.43)$ & $20.07(4.71)$ & $20.93(4)$ & 0.2854 \\
\hline VIT & VI thickness anterior region & $12.07 \pm 2.80$ & $12.81 \pm 2.48$ & $14.41 \pm 3.38$ & $0.0226 \dagger$ \\
\hline TT & Total quadriceps thickness (RFT + VIT) & $33.01 \pm 4.77$ & $34.16 \pm 5.06$ & $36.08 \pm 5.14$ & 0.0985 \\
\hline $\mathrm{CTL}^{*}$ & Subcutaneous cell tissue thickness lateral region & $4.28(3.93)$ & $5.86(2.93)$ & $6.93(4.43)$ & $0.0343+$ \\
\hline VLT & VL thickness & $14.04 \pm 2.93$ & $13.94 \pm 3.47$ & $14.34 \pm 2.79$ & 0.9325 \\
\hline VIL* & VI lateral region & $10.71(3.43)$ & $12.43(4.35)$ & $13.57(1.07)$ & $0.0043+\dagger$ \\
\hline TTL & Total thickness lateral region (VLT+VIT) & $27.24 \pm 3.93$ & $27.86 \pm 6.28$ & $30.18 \pm 4.96$ & 0.088 \\
\hline $\mathrm{ARF}^{*}$ & Penetration angle of the rectus femoris & $12.87(3.66)$ & $12.6(2.68)$ & $10.79(1.42)$ & $0.024+$ \\
\hline $\mathrm{AVL}^{*}$ & Penetration angle of the vastus lateralis & $14.51(3.97)$ & $11.67(2.43)$ & $12.13(1.46)$ & $0.0018+\dagger$ \\
\hline
\end{tabular}

The data are presented as arithmetic measure \pm standard deviation; *The data are presented as median (interquartile range); $\uparrow \mathrm{p} \leq 0.05 ;+\uparrow \mathrm{p} \leq 0.01$. 
Table 3. Distribution of the quantitative ultrasound characteristics according to sport type.

\begin{tabular}{|c|c|c|c|c|c|c|}
\hline & \multicolumn{3}{|c|}{ Boys } & \multicolumn{3}{|c|}{ Girls } \\
\hline & $\begin{array}{c}\text { Multisport } \\
n=15\end{array}$ & $\begin{array}{c}\text { No sport } \\
n=13\end{array}$ & $p$ value & $\begin{array}{c}\text { Multisport } \\
n=43\end{array}$ & $\begin{array}{c}\text { No sport } \\
n=31\end{array}$ & $p$ value \\
\hline $\mathrm{FEI}^{*}$ & $145.47(11.36)$ & $141.16(11.57)$ & 0.6177 & $142.04(11.49)$ & $142.43(9.91)$ & 0.7306 \\
\hline EIRF & $168.85 \pm 13.89$ & $164.72 \pm 15.47$ & 0.4629 & $169.60 \pm 13.89$ & $169.17 \pm 15.40$ & 0.9004 \\
\hline FPRF & $20.36 \pm 1.28$ & $19.97 \pm 1.42$ & 0.4531 & $20.43 \pm 1.28$ & $20.39 \pm 1.42$ & 0.8997 \\
\hline EIVIA & $145.28 \pm 12.81$ & $148.92 \pm 11.54$ & 0.4399 & $151.85 \pm 14.67$ & $153.15 \pm 15.68$ & 0.7149 \\
\hline FPV I & $21.72 \pm 1.45$ & $22.15 \pm 1.30$ & 0.4406 & $22.49 \pm 1.66$ & $22.64 \pm 1.77$ & 0.7128 \\
\hline Dif 1 & $-24.61 \pm 18.43$ & $-21.46 \pm 20.88$ & 0.6753 & $-27.43 \pm 16.42$ & $-25.89 \pm 19.28$ & 0.7102 \\
\hline Dif 2 & $-1.03 \pm 17.31$ & $-5.65 \pm 16.49$ & 0.4777 & $-9.68 \pm 16.21$ & $-9.86 \pm 18.91$ & 0.9644 \\
\hline Dif3 & $-12.82 \pm 16.86$ & $-13.56 \pm 17.82$ & 0.9112 & $-18.56 \pm 14.99$ & $-17.88 \pm 18.33$ & 0.8604 \\
\hline LFEI & $134.45 \pm 11.19$ & $138.55 \pm 9.12$ & 0.3027 & $138.56 \pm 7.87$ & $134.60 \pm 5.64$ & $0.0191 \dagger$ \\
\hline EIVL & $168.23 \pm 16.33$ & $170.53 \pm 11.76$ & 0.6772 & $172.11 \pm 13.42$ & $171.01 \pm 12.40$ & 0.7206 \\
\hline FPVL & $24.37 \pm 1.85$ & $24.63 \pm 1.32$ & 0.6859 & $24.81 \pm 1.52$ & $24.68 \pm 1.40$ & 0.7199 \\
\hline EIVIE & $137.77 \pm 13.77$ & $142.16 \pm 11.26$ & 0.3689 & $150.70 \pm 15.61$ & $150.88 \pm 13.23$ & 0.9582 \\
\hline FPVIE & $20.90 \pm 1.56$ & $21.39 \pm 1.28$ & 0.3756 & $22.37 \pm 1.77$ & $22.39 \pm 1.50$ & 0.9568 \\
\hline Dif 4 & $-33.78 \pm 15.33$ & $-31.91 \pm 9.83$ & 0.7191 & $-33.54 \pm 11.71$ & $-36.41 \pm 13.03$ & 0.3233 \\
\hline Dif $5^{*}$ & $-4.85(32.32)$ & $-5.01(22.11)$ & 0.9639 & $-14.70(20.93)$ & $-14.69(14.94)$ & 0.327 \\
\hline Dif $6^{*}$ & $-22.15(24.64)$ & $-19.28(13.18)$ & 0.7168 & $-23.09(13.02)$ & $-25.92(15.61)$ & 0.3377 \\
\hline $\mathrm{SCT}^{*}$ & 7.86 (3.79) & $9.57(5.43)$ & 0.5942 & $8.42(3.12)$ & $7.78(5.14)$ & 0.7995 \\
\hline $\mathrm{RFT}^{*}$ & $20.07(4.71)$ & $20.93(4)$ & 0.413 & $17.61(2.96)$ & $16.36(3)$ & $0.0221 \dagger$ \\
\hline VIT & $12.81 \pm 2.48$ & $14.41 \pm 3.38$ & 0.1624 & $13.26 \pm 2.50$ & $14.25 \pm 3.23$ & 0.1382 \\
\hline TT & $34.16 \pm 5.06$ & $36.08 \pm 5.14$ & 0.3295 & $33.20 \pm 4.28$ & $32.62 \pm 4.60$ & 0.5718 \\
\hline$C T L^{*}$ & $5.86(2.93)$ & $6.93(4.43)$ & 0.2124 & 6.36 (2.99) & $5.78(3.21)$ & 0.5945 \\
\hline VLT & $13.94 \pm 3.47$ & $14.34 \pm 2.79$ & 0.7437 & $12.57 \pm 2.50$ & $13.44 \pm 2.57$ & 0.149 \\
\hline VIL* & $12.43(4.35)$ & $13.57(1.07)$ & 0.2589 & $11.21(3.50)$ & $11.14(3.36)$ & 0.659 \\
\hline TTL & $27.86 \pm 6.28$ & $30.18 \pm 4.96$ & 0.2938 & $26.25 \pm 3.85$ & $26.94 \pm 4.35$ & 0.4667 \\
\hline ARF* & $12.6(2.68)$ & $10.79(1.42)$ & $0.0052+\dagger$ & $11.75(3.28)$ & $10.86(2.13)$ & 0.1419 \\
\hline AVL* & $11.67(2.43)$ & $12.13(1.46)$ & 0.7168 & $12.48(3.34)$ & $11.29(1.26)$ & $0.0176 \dagger$ \\
\hline
\end{tabular}

The data are presented as arithmetic measure \pm standard deviation; ${ }^{*}$ The data are presented as median (interquartile range); $\dagger p \leq 0.05 ;+\uparrow p \leq 0,01$.

present study, the decrease of El could be due to a muscle fiber increase, caused by the different type of sport initiation (practice regularity, training content orientation, etc.). According to the results obtained in this study, quantitative ultrasonography could accurately measure the changes in muscle size, especially muscle thickness, with an excellent correlation with the physiological cross-section area ${ }^{21,22}$. El is modified by training in adult people $e^{23}$, and fat replacement is the main cause of muscle El increase in them ${ }^{8}$. The results of a different study indicate that, for adolescent children, leg muscle quality is not significantly influenced by maturation ${ }^{24}$. A study conducted with men aged between 19 and 68 years compared muscle fat, measured by US, with health and physical activity indicators, and concluded that intramuscular fat was inversely associated with physical activity ${ }^{25}$. In our study, the differences found in the analysed groups show that there is a relationship between physical stimuli and changes in muscle quality. The main difference was the decrease of El, which has not been explained yet in children. A possible explanation would be the decrease of intramuscular fat, measured by ultrasonography, with an increase of muscle fiber size. According to these results, ultrasonography could be considered as a tool to measure the effects of exercise performed by children, in terms of proper stimuli to generate measurable muscle changes. The statistical difference in these components of the quadriceps may be due to the specialisation of the training carried out by the soccer group, who performed a larger number of specific kicking exercises, with a greater orientation to physical work for the muscle groups evaluated and, particularly, the rectus femoris. However, this did not happen in the multisport group, whose practice frequency was lower, as well as the orientation of their exercises, which were rather focused on coordination work and motor competence, with conditional capacities such as strength being less important. This fact suggests that there are no significant differences between the multisport group and the no sport group in both genders. It is worth highlighting the subtraction of fat El minus muscle El, measured in our study with variables Dif1 and Dif3, which showed statistically significant differences. As an internal reference of the subject, subcutaneous fat tissue El allows its comparison with other ultrasound results, offering a way to better evaluate the changes generated by physical activity in 
schoolchildren. This could be a useful tool to determine whether the type of physical exercise performed by the child is enough to generate changes in muscle tissue, which is the main tissue involved in both movement and metabolic aspects.

\section{Fat and muscle thickness}

Mean fat thickness in the anterior and lateral regions was different and statistically significant between the three groups of children. The lowest values were obtained in the soccer group, whereas the highest values were shown by the no sport group, who did not perform any physical practice on a regular basis. These results corresponded to the fat percentage measured by skinfold (Table 1). Between the multisport and no sport groups, the differences were not significant, neither in boys nor girls. These results suggest that the specific components of sport and, specifically, the orientation of the training contents, could be intense, long and frequent enough to maintain the fat values under the values of children who do not exercise regularly. This could help to establish reference indicators, which, in addition, would be consistent with some of the recommendations found in the literature about the characteristics of exercise in minors ${ }^{26}$.

The thickness of the vastus intermedius measured in the anterior and external regions (VIT, VITE) was significantly different between the three groups, with the lowest values in the soccer group. There were no differences in muscle thickness between the multisport and no sport groups in boys, whereas in girls there was a significant difference only in RFT. Muscle thickness and, particularly, the diameter of human muscle fibre, increase with age $e^{6,27-29}$, which is in line with the results of our study, since the mean age of the groups is lower in the soccer group and higher in the no sport group, in both boys and girls (boys: "soccer":

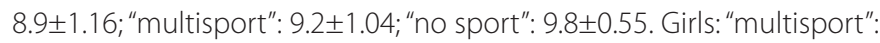

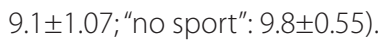

\section{Pennation angle}

The difference in pennation angle was statistically significant in boys for the two muscles evaluated, i.e., rectus femoris and vastus lateralis, between the three groups. Between the multisport and no sport groups, there were significant differences in ARF in boys and in AVL in girls. All these differences caused an increase in the pennation angle in the soccer group with respect to the other two groups, and in the multisport group with respect to the no sport group. These results are in line with the idea that a greater pennation angle is related to greater muscle strength ${ }^{30,31}$. In our case, the differences in the pennation angle could be determined by a higher frequency of sport stimuli (longer weekly practice time), which was different depending on the type of sport initiation of the evaluated sample. Despite the similarities in the use of the quadriceps in the different sports practised by the children of this study, such as jumping, running and changes of direction, the frequency of kicking in soccer makes those who practise this sport activate it more often in the training session, since this movement specifically stimulates the rectus femoris ${ }^{32,33}$. Thus, it would meet one of the principles of adaptation to training, i.e., the specificity principle ${ }^{34}$, which would explain the obtained results. However, it must be taken into account that these results may be determined by the higher frequency and duration of the training in the soccer group with respect to the other two groups.

\section{Conclusions}

In view of the results obtained in this study, it can be asserted that the orientation of the training contents in sport initiation, in children aged between 7 and 10 years, may generate differences in the quadriceps, which can be shown by quantitative muscle ultrasonography Such changes would be related to the duration and frequency of stimuli, which can be a useful tool for trainers in the planning of the training contents. This can induce a qualitative improvement of the effect of the exercises, determined by their specific orientation.

\section{Limitations}

Due to the inherent difficulties of research in our area, mainly caused by the scarcity of financial resources and the social conditions of the city, it was not possible to recruit a larger sample, to include, for instance, a greater number of girls in the soccer group. Furthermore, the results are determined by the difference in the number of practice days per week. Future studies should compare groups with different types of sport initiation and the same frequency of weekly practice.

\section{Conflict of interest}

The authors do not declare a conflict of interest.

\section{Bibliography}

1. Van Praagh E, Doré E. Short-term muscle power during growth and maturation. Sport Med. 2002;32:701-28

2. Malina RM, Bouchard C, Bar-Or O. Skeletal muscle tissue. En: Patterson J, Feld M. Growth maturation, and physical activity. Champaign. Human kinetics; 2004. p. 137-57.

3. Melvin MN, Smith-Ryan AE, Wingfield HL, Ryan ED, Trexler ET, Roelofs EJ. Muscle characteristics and body composition of NCAA division I football players. J Strength Cond Res. 2014;28:3320-9.

4. Heredia JM, Tejada V, Ventaja J, Orantes E. Valoración de la grasa corporal: ultrasonidos frente a sistemas de bioimpedancia tetrapolar y antropometría. Estudio piloto. Arch Med Deporte. 2015;32:20-4.

5. Fukunaga T, Funato $K$. The effects of resistance training on muscle area and strength in prepubescent age. Ann Physiol Anthropol. 1992;11:357-64.

6. Jacobs J, Jansen M, Janssen H, Raijmann W, Van Alfen N, Pillen S. Quantitative muscle ultrasound and muscle force in healthy children: A 4-year follow-up study. Muscle Nerve. 2013;47:856-63

7. Scholten RR, Pillen S, Verrips A, Zwarts MJ. Quantitative ultrasonography of skeleta muscles in children: normal values. Muscle Nerve. 2003;27:693-8.

8. Reimers K, et. al. Skeletal muscle sonography: a correlative study of echogenicity and morphology. J Ultrasound Med. 1993;12:73-7.

9. Melvin MN, Smith-Ryan AE, Wingfield HL, Fultz SN, Roelofs EJ. Evaluation of muscle quality reliability and racial differences in body composition of overweight individuals. Ultrasound Med Biol. 2014;40:1973-9.

10. Akagi R, Kanehisa H, Kawakami Y, Fukunaga T. Establishing a new index of muscle cross-sectional area and its relationship with isometric muscle strength. J Strength Cond Res. 2008;22:82-7.

11. Keller BA. State of the Art Reviews: Development of fitness in children: The Influence of Gender and Physical Activity. Am J Lifestyle Med. 2008;2:58-74.

12. González S, García L, Contreras O, Sánchez Mora D. El concepto de iniciación deportiva en la actualidad. Retos. 2009;15:14-20. 
13. Mundy LK, Simmons JG, Allen NB, Viner RM, Bayer JK, Olds T, et al. Study protocol: the childhood to adolescence transition study (CATS). BMC Pediatr. 2013;13:160-72.

14. Dew AP, Moreau NG. A comparison of 2 techniques for measuring rectus femoris muscle thickness in cerebral palsy. Pediatr Phys Ther. 2012;24:218-22.

15. Caresio C, Molinari F, Emanuel G, Minetto MA. Muscle echo intensity: reliability and conditioning factors. Clin Physiol Funct Imaging. 2015;35:393-403.

16. Young H, Jenkins NT, Zhao Q, Mccully KK. Measurement of intramuscular fat by muscle echo intensity. Muscle Nerve. 2015;52:963-71.

17. Wu JS, Darras BT, Rutkove SB. Assessing spinal muscular atrophy with quantitative ultrasound. Neurology. 2010;75:526-31.

18. Gómez R, De Marco A, De Arruda M, Martínez C, Salazar C, Valgas C, et al. Predicción de ecuaciones para el porcentaje de grasa a partir de circunferencias corporales en niños pre-púberes. Nutr Hosp. 2013;28:772-8.

19. Ng KW, Connolly AM, Zaidman CM. Quantitative muscle ultrasound measures rapid declines over time in children with SMA type 1. J Neurol Sci. 2015;358:178-82.

20. Rutkove SB, Geisbush TR, Mijailovic A, Shklyar I, Pasternak A, Visyak N, et al. Crosssectional evaluation of electrical impedance myography and quantitative ultrasound for the assessment of Duchenne muscular dystrophy in a clinical trial setting. Pediatr Neurol. 2014;51:88-92

21. Stock MS, Mota JA, Hernandez JM, Thompson BJ. Echo intensity and muscle thickness as predictors of athleticism and isometric strength in middle-school boys. Muscle Nerve. 2017;55:685-92.

22. Kleinberg CR, Ryan ED, Tweedell AJ, Barnette TJ, Wagoner CW. Influence of lower extremity muscle size and quality on stair-climb performance in career firefighters. $J$ Strength Cond Res. 2016;30:1613-8.

23. Mota JA, Stock MS, Thompson BJ. Vastus lateralis and rectus femoris echo intensity fail to reflect knee extensor specific tension in middle-school boys. Physiol Meas. 2017:38:1529-41.
24. Fukunaga Y, Takai Y, Yoshimoto T, Fujita E, Yamamoto M, Kanehisa H. Effect of maturation on muscle quality of the lower limb muscles in adolescent boys. J Physiol Anthropol. 2014;33:30.

25. Young H, Southern WM, Mccully KK. Comparisons of ultrasound-estimated intramuscular fat with fitness and health indicators. Muscle Nerve. 2016;54(4):743-9.

26. WHO. Recomendaciones mundiales sobre actividad física para la salud. Ginebra: Organización Mundial de la Salud. 2010. (Accessed June 2019). Available: http:// whqlibdoc.who.int/publications/2010/9789243599977_spa.pdf

27. Lin JP, Brown JK, Walsh EG. Physiological maturation of muscles in childhood. Lancet. 1994:343:1386-9.

28. Ozdemir H, Sedef K, Konus O, Aytekin C, Onal B, Ataman A, et al. Quadriceps muscle thickness and subcutaneous tissue thickness in normal children in Turkish population: sonographic evaluation. Gazi Med J. 1995;6:141-4

29. Kanehisa $H_{\text {, Yata }} H_{\text {, Ikegawa }}$, Fukunaga T. A cross-sectional study of the size and strength of the lower leg muscles during growth. Eur J Appl Physiol. 1995;72:150-6.

30. Alegre L, Lara A, Abián J, Jiménez L, Ureña A, Aguado X. Arquitectura muscular en cuatro grupos de mujeres jóvenes. Arch Med Deporte. 2006;23:265-73.

31. Moreau NG, Simpson KN, Teefey SA, Damiano DL. Muscle architecture predicts maximum strength and is related to activity levels in cerebral palsy. Phys Ther. 2010;90:1619-30.

32. Cerrah AO, Gungor EO, Soylu AR, Ertan H, Lees A, Bayrak C. Muscular activation patterns during the soccer in-step kick. Isokinet Exerc Sci. 2011;19:181-90.

33. Robertson D, Mosher R. Work and power of the leg muscles in soccer kicking. Biome chanics IX-b. 1985;533-8

34. Billat V. Fisiología y metodología del entrenamiento. De la teoría a la práctica. Barcelona Editorial Paidotribo; 2002. p. 168. 